\title{
A STUDY OF NAPHTHIONIN, A NEW HAEMOSTATIC DRUG
}

\author{
BY \\ L. POLLER \\ From the Medical Division, Chemical Defence Experimental Establishment, Ministry of Supply, Porton
}

(RECEIVED FOR PUBLICATION MARCH 25, 1955)

The emphasis has shifted in recent years from arbitrary methods used in the treatment of bleeding diseases to the search for the individual factors underlying these conditions. The haemorrhagic diathesis in haemophilia, hypoprothrombinaemia, Christmas disease, and others can now be treated with the specific clotting factor found to be deficient.

There remain a number of conditions, e.g., peptic ulceration, operative surgery, obstetrical haemorrhages, in which there is danger to life from bleeding although the coagulation process is not at fault. The acceleration or promotion of haemostasis in these states would be of the greatest benefit.

Esteve, Oriol, and Regné (1949) employed "naphthionin" (sodium-alpha-naphthylamine-4sulphonate) in an effort to produce a substance which would be of use in the prophylaxis and treatment of vascular haemorrhage. Naphthionin is related to Congo red, which had been claimed to be of value in the treatment of the haemorrhagic tendency in thrombocytopenic purpura (Brühl, 1933).

The effects of "naphthionin" in vitro and in vivo on a group of healthy adult males have been assessed in this paper.

\section{Methods}

Lee and White (1913) Clotting Method (Modified).Blood (5 ml.) was withdrawn into a dry syringe from an antecubital vein of a healthy adult in the minimum time after the application of a tourniquet. The whole process was accomplished in under 30 seconds. Three $1 \mathrm{ml}$. amounts of blood were delivered into three $3 \times \frac{3}{8}$ in. test-tubes which had been allowed to warm to $37^{\circ} \mathrm{C}$. in a water-bath.

The residual $2 \mathrm{ml}$. of blood in the syringe was discarded to reduce contamination by tissue juices rich in thromboplastin. As soon as the first blood had entered the syringe timing was begun with a stopwatch.

The first tube was tilted gently at 30 -second intervals until a firm, totally adherent clot formed, not being dislodged by complete inversion of the tube. This was regarded as the end-point in the clotting reaction and the same procedure repeated on the second and third tubes.

Prothrombin Estimations.-Prothrombin times were based on the Quick single-stage principle (Quick, 1944) using a human brain thromboplastin extract. This gave a normal reading of 12 to 14 seconds using $1 \%$ potassium oxalate as the anticoagulant and $0.2 \%$ calcium chloride.

Bleeding Times.-The method of Duke (1915) was employed. Blotting was performed at 15 -second intervals.

Heparin-retarded Plasma Clotting Times.-The method of Poller (1954) was used. A slight deviation from the technique previously described was the performance of the test $\mathbf{3 0}$ minutes after collection. This has resulted in longer clotting times owing to the reduction of the effects of storage of oxalated plasma in glass.

Inhibited clotting methods whether by the use of silicone glassware or heparin are attempts to achieve more sensitive tests for the clotting mechanism than those in routine clinical use.

\section{Results}

In Vitro Tests. -Naphthionin was diluted 60 times and $0.1 \mathrm{ml}$. containing $1 / 6,000 \mathrm{~g}$. was added to the $3 \times \frac{3}{8}$ in. test-tubes employed for the Lee and White clotting test. This gave a level roughly equivalent to blood level after a $1 \mathrm{~g}$. injection of blood had been delivered for the Lee and White test.

To a second tube $0.1 \mathrm{ml}$. of normal saline was added as a control before the addition of blood for the clotting test.

TABLE I

EFFECT OF NAPHTHIONIN AT EQUIVALENT BLOOD CONCENTRATIONS ON THE LEE AND WHITE CLOTTING TEST IN VITRO

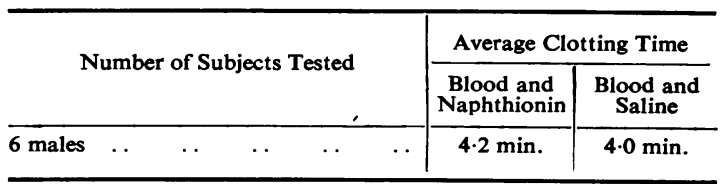


It appears that " naphthionin" has no dramatic immediate effect on whole blood clotting times.

Response to Intravenous Naphthionin in Healthy Aduk Males.-The effect of the intravenous administration of $10 \mathrm{ml}$. (1 g.) "naphthionin" has been observed in 10 healthy young adult males.

Before injection the bleeding time, clotting time (by the modified Lee and White method), prothrombin time, and the heparin retarded clotting time were estimated.

Ten millilitres $(1 \mathrm{~g}$.$) of the drug was injected.$ Bleeding times, clotting times, and prothrombin times were repeatedly tested at 30-minute intervals over a three-hour period while heparin-retarded tests were repeated hourly.

The effect on bleeding, clotting, and prothrombin times may be observed in Figs. 1 and 2 .

The significant result was the appreciable reduction of the bleeding time, which appeared to be greatest one hour after injection. The bleeding time is a crude test, yet the differences noted are reasonably marked. The mean deviation is 0.775 , which is significantly different from zero $(\mathrm{P}<1 \%)$.

TABLE II

EFFECT OF INTRAVENOUS ADMINISTRATION OF NAPHTHIONIN ONE HOUR AFTER INJECTION OF 1 G. (10 ML.)

\begin{tabular}{|c|c|c|c|c|c|c|c|c|}
\hline \multirow{2}{*}{$\begin{array}{c}\text { Total } \\
\text { Sub- } \\
\text { jects }\end{array}$} & \multicolumn{2}{|c|}{$\begin{array}{c}\text { Modified } \\
\text { Lee and White } \\
\text { Test }\end{array}$} & \multicolumn{2}{|c|}{$\begin{array}{l}\text { Bleeding } \\
\text { Time }\end{array}$} & \multicolumn{2}{|c|}{$\begin{array}{l}\text { Prothrombin } \\
\text { Time }\end{array}$} & \multirow{2}{*}{$\begin{array}{c}\begin{array}{c}\text { Heparin } \\
\text { Clot- } \\
\text { ting }\end{array} \\
\begin{array}{c}\text { Initial } \\
14 \cdot 3 \\
\text { min. }\end{array}\end{array}$} & \multirow{2}{*}{ 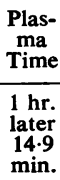 } \\
\hline & $\begin{array}{c}\text { Initial } \\
7 \cdot 3 \\
\text { min. }\end{array}$ & $\begin{array}{l}1 \mathrm{hr} . \\
\text { later } \\
7.36 \\
\text { min. }\end{array}$ & $\begin{array}{c}\text { Initial } \\
2 \cdot 35 \\
\text { min. }\end{array}$ & $\begin{array}{l}1 \mathrm{hr} . \\
\text { later } \\
1.37 \\
\text { min. }\end{array}$ & $\begin{array}{l}\text { Initial } \\
14 \mathrm{sec} .\end{array}$ & $\begin{array}{l}1 \mathrm{hr} . \\
\text { later } \\
14 \mathrm{sec} .\end{array}$ & & \\
\hline
\end{tabular}

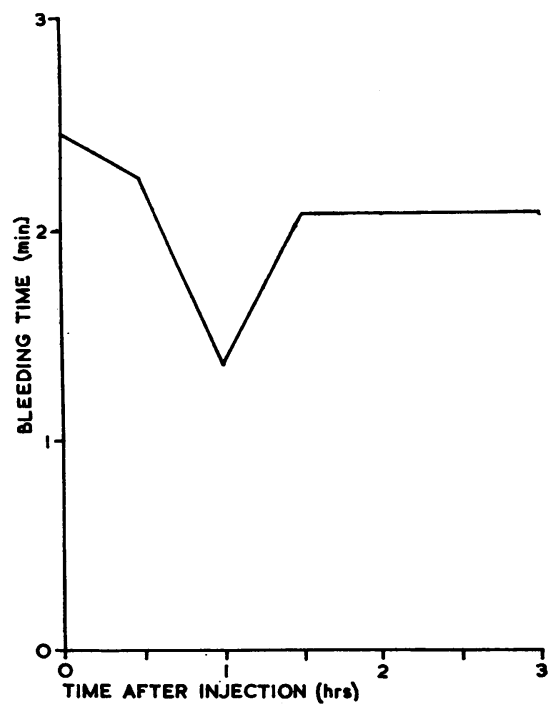

FiG. 1.-Effect of intravenous administration of $10 \mathrm{ml}$. " naphthionin " ( 1 g.) on bleeding time (Duke's method).
No significant change was observed in the clote ting times-heparin-retarded plasma clotting o $\overrightarrow{5}$ prothrombin times.

\section{Discussion}

Several papers have been published describing the clinical benefit of the drug in the preventions and treatment of haemorrhage (Dubois-Ferrière 1950 ; Puigvert, Cols, Mas-Oliver, and Nogueraø 1951 ; Greif, 1952 ; Rambauske, 1953 ; Pirquet, 1954). It has now been made generally available? in this country.

Hitherto no adequate attempt to assess the action of the drug has been reported.

The present findings do not support the vievio (based mainly on capillary clotting times in rabbitsf that "naphthionin" in a dosage of $1 \mathrm{~g}$. $(10 \mathrm{ml}$. causes a marked reduction in blood coagulation times in man.

Naphthionin lowers the iso-electric point of plasma proteins, including fibrinogen, with the result that in blood with a $p H$ in the region of 7.3 the passage from sol to gel state is facilitated

The tendency to gel formation was observed in the course of performing the Lee and White testse and, unless the formation of a firm, totally adhêr ent clot had been regarded as the end-point, this would have caused difficulty with readings.

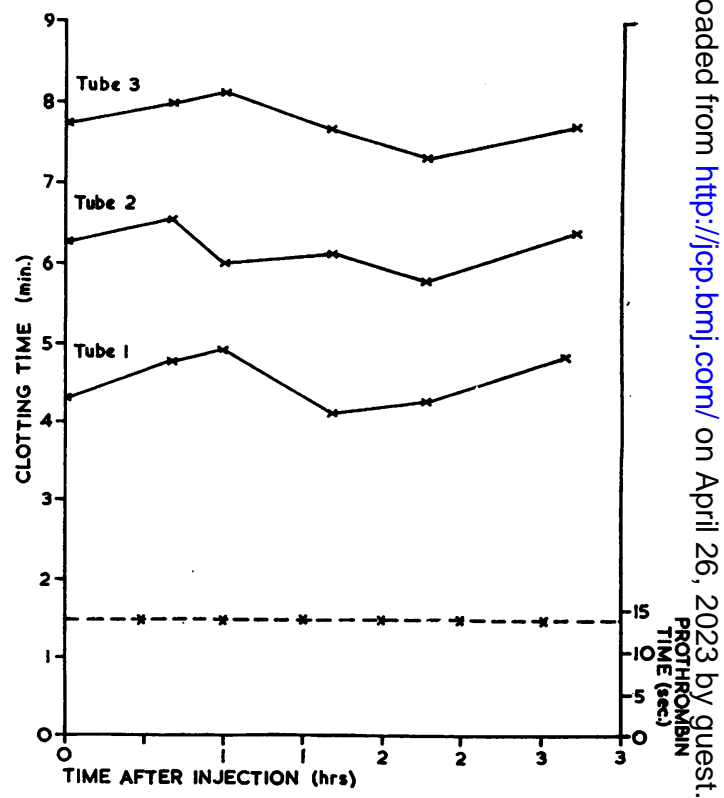

FIG. 2.-Average graph based on six normal adults, showing the effect of intravenous administration of " naphthionin" $(10 \mathrm{ml} .=\overline{0}$ 1 g.) on the modified Lee and White clotting time, and off prothrombin by the Quick single-stage method. 
formation of a gel would have been particularly prone to give low readings in the outmoded capillary and slide clotting methods which previously have been used to investigate this drug, and is perhaps the reason why shortening of clotting times was observed with these unreliable techniques (Dubois-Ferrière, 1950).

\section{Conclusion}

Naphthionin has an appreciable effect on haemostasis as measured by bleeding times in man but no appreciable effect on blood clotting. The mechanism of this action may be due to the tendency to gel formation resulting from the lowering of the iso-electric point of fibrinogen with the result that small capillary punctures are more easily sealed off.

\section{Summary}

A study has been made of a new haemostatic drug, " naphthionin," which has recently been made generally available in this country.

This drug causes marked reduction of bleeding times but no effect on blood coagulation as measured by the modified Lee and White clotting time, the heparin-retarded plasma clotting time, or prothrombin time.
The haemostatic action of "naphthionin" appears to be an effect on the smaller vessels and is possibly due to the tendency to gel formation resulting from the lowering of the iso-electric point of fibrinogen nearer to blood $p \mathrm{H}$ level by "naphthionin."

Samples of " naphthionin " were generously supplied by Maw and Sons Ltd.

Dr. L. Stent, Withington Hospital, Manchester, provided the human brain thromboplastin employed in the prothrombin estimations.

I am indebted to Dr. Cullumbine for encouragement in this work.

\section{REFERENCES}

Brahl, H. (1933). Z. Kinderheilk., 54, 159.

Dubois-Ferrière, H. (1950). Schweiz. med. Wschr., 80, 861.

Duke, W. W. (1915). J. Amer. med. Ass., 65, 1600.

Esteve, A., Oriol, A., and Regné, F. (1949). "Coagulants Synthétiques." Comm. XXII Congrès Internat. de Chimie Industr. Barcelona.

Greif, S. (1952). Ars Medici, Bâle, 4, 263.

Lee, R. I., and White, P. D. (1913). Amer. J. med. Sci., 145, 495.

Pirquet, S. R. (1954). Praxis, 43, 321.

Poller, L. (1954). Angiology, 5, 21.

Puigvert, A., Cols, A., Mas-Oliver, A., and Noguera, A. (1951). Schweiz. med. Wschr., 81, 1280.

Quick, A. J. (1944). Physiol. Rev., 24, 297.

Rambauske, K. (1953). Prakt. Arzt., 76515. 